\title{
PELATIHAN PENYUSUNAN SOAL MENGGUNAKAN KAHOOT DAN VALIDITAS SOAL MENGGUNAKAN MODEL RASCH UNTUK GURU MATEMATIKA SMK KOTA BATU
}

\author{
L.T.Oktoviana ${ }^{1}$, S. Rahardjo ${ }^{2}$, I.N.Hidayah ${ }^{3}$, T.E.Lestari ${ }^{4}$, M. Agung ${ }^{5}$, Azizah $^{6}$ \\ Universitas Negeri Malang \\ ${ }^{1}$ lucky.tri.fmipa@um.ac.id; ${ }^{2}$ swasono.rahardjo.fmipa@um.ac.id; \\ 3indriati.nurul.fmipa@um.ac.id; ${ }^{4}$ trianingsih.eni.fmipa@um.ac.id; \\ ${ }^{5}$ mohammad.agung.fmipa@um.ac.id; ${ }^{6}$ azizah.fmipa@um.ac.id
}

\begin{abstract}
Assessment attempts to obtain information from the learning process and results. A good assessment process is supported by good quality questions and can provide complete details on student abilities. The method that can be used is the Rasch model measurement (Rasch model measurement) on the test result data. One of the uses of technology in the assessment is preparing interactive online questions. One application that can be used to prepare online questions is the Kahoot application which is based on a free learning platform. The target of this community service activity is vocational mathematics teachers in Batu City. They are members of the Batu City Vocational Mathematics MGMP. as well as the validity of the test questions made. The mechanism for implementing this activity is carried out by adopting action research steps consisting of 4 (four) stages: planning, action, observation and evaluation, and reflection. In the action stage, the implementation of the service is carried out into two workshop activities which are carried out online. The first workshop provides materials for making questions and Kahoot applications. In contrast, the second workshop begins with a review of the uploaded assignments from the first workshop and the provision of Rasch modelling materials with Ministep application tools.
\end{abstract}

Keywords: mathematics problem, Kahoot, Rasch Model

\section{PENDAHULUAN}

Asesmen merupakan upaya untuk mendapatkan informasi dari proses dan hasil pembelajaran. Dari hasil wawancara guru matematika SMK Kota Batu menunjukkan dalam penyusunan soal tes belum dilakukan validitas soal tes. Proses assesmen yang baik didukung oleh kualitas soal yang baik dan bisa memberikan informasi yang lengkap dari abilitas siswa. Metode yang dapat digunakan adalah pengukuran pemodelan Rasch (Rasch model measurement) pada data hasil ujian. Tujuan pemodelan Rasch adalah menghasilkan suatu skala pengukuran dengan interval yang sama yang bisa memberikan informasi secara akurat tentang peserta tes maupun kualitas soal yang diujikan. Seperti pada penelitian yang menggunakan Pemodelan Rasch untuk validasi instrumen oleh Yasin dkk.(2015), dan Garcia Claro dkk., (2015).

Adanya pandemi covid-19, guru dituntut memanfaatkan teknologi dalam pembelajaran. Salah satu upaya yang dilakukan adalah mengintegrasikan teknologi dalam pembelajaran dan asesmen (Heuvel-Panhuizen dkk., 2011). Berdasarkan penelitian yang sudah dilakukan menunjukkan pemanfaatan media pembelajaran dalam kelas sangat membantu menarik minat siswa dalam proses belajar di kelas. Hal ini sesuai dengan hasil penelitian Sulastri (2018), Wahyuni (2016) dan Rohma (2018). Penelitian lainnya dilakukan oleh Sahronih, dkk (2019) yang membahas pengaruh penggunaan multimedia terhadap hasil belajar.

Pemanfaatan teknologi dalam asesmen salah satunya adalah penyusunan soal online yang interaktif. Salah satu aplikasi yang dapat digunakan dalam penyusunan soal online adalah aplikasi Kahoot yang berbasis platform pembelajaran gratis. Kahoot memungkinkan guru untuk membuat kuis, diskusi, maupun pertanyaan dengan memasukkan berbagai elemen seperti video, gambar maupun teks. Kahoot membua 
pembelajaran menjadi menyenangkan karena disetting seperti permainan (Sabandar dkk., 2018).

Berdasarkan latar belakang di atas akan dilakukan kegiatan pengabdian dengan melakukan pelatihan penyusunan soal dengan Kahoot dan Validitas soal menggunakan pemodelan Rasch. Sasaran dari kegiatan pengabdian ini adalah guru matematika SMK di Kota Batu yang tergabung dalam MGMP Matematika SMK Kota Batu. Adanya pelatihan ini bertujuan meningkatkan motivasi guru-guru SMK dalam pemanfaatan teknologi untuk meningkatkan kualitas pembelajaran daring baik dari segi penyusunan soal, media soal online maupun validitas dari soal tes yang dibuat.

\section{METODE}

Rancangan mekanisme pelaksanaan kegiatan ini dilakukan dengan mengadopsi langkah-langkah action research yang terdiri dari 4 (empat) tahapan, yaitu: perencanaan, tindakan, observasi dan evaluasi, serta refleksi. Kegiatan-kegiatan atau aktivitas-aktivitas dari masing-masing tahapan adalah sebagai berikut:

1. Perencanaan

Pada tahap ini tim pengabdian melakukan identifikasi masalah, analisis permasalahan yang ada, analisis kebutuhan, dan analisis potensi sekolah, selanjutnya tim pengabdian menyusun program pelatihan. Hasil yang diperoleh pada tahap ini adalah kegiatan pengabdian kepada masyarakat ini berupa pelatihan penyusunan soal online menggunakan aplikasi kahoot dan validitas soal menggunakan Rasch model, yang dilaksanakan pada bulan April sampai September 2021. Kegiatan ini akan dilangsungkan secara daring. Peserta pada kegiatan ini adalah guru - guru matematika SMK yang tergabung dalam MGMP matematika SMK kota Batu.

2. Tindakan

Tindakan dalam kegiatan ini berupa tahap pelaksanaan yang dikemas melalui kegiatan workshop. Kegiatan ini terdiri atas 2 pertemuan yang dilakukan secara daring. Kegiatan daring dilakukan secara sinkron dan asinkron. Kegiatan asinkron berupa aktivitas peserta untuk mengerjakan tugas secara mandiri yang diberikan oleh pemateri di luar waktu sinkron. Tugas diberikan kepada peserta ketika kegiatan sinkron.

Dalam kegiatan ini, tim pengabdian berperan menjadi narasumber dan pendamping dalam penyusunan dan analisis soal. Keterlaksanaan kegiatan pengabdian ini sangat ditunjang oleh peran aktif dari para peserta dalam menyusun soal dan memvalidasinya. Secara umum pelatihan ini terdiri atas dua kegiatan sinkron yang mencakup pendampingan dalam menyusun soal, membuat soal yang telah disusun ke dalam bentuk online menggunakan aplikasi Kahoot, menganalisis soal menggunakan Rasch model, dan pendampingan dalam penggunaan software ministep untuk melakukan analisis soal.

3. Observasi dan evaluasi

Observasi dilakukan terhadap proses pembuatan soal online dengan aplikasi Kahoot oleh guru-guru SMK. Instrumen yang digunakan berupa catatan lapangan. Beberapa hal yang diobservasi adalah kendala-kendala, kekurangan-kekurangan, dan kelemahan-kelemahan yang muncul dalam proses pembuatan di lapangan maupun dalam proses penggunaan di kelas. Evaluasi dilakukan terhadap kuantitas dan kualitas produk yang dihasilkan. Produk yang dihasilkan berupa soal online yang sudah dibuat dengan bantuan aplikasi Kahoot dan sudah diaplikasikan kepada siswa serta hasil validasi soal dengan menggunakan mini step. Kuantitasnya dilihat dari berapa produk yang dihasilkan oleh para guru, sedangkan kualitasnya terlihat dari 
hasil validasi soal yang dibuat menggunakan model Rasch dengan bantuan aplikasi ministep.

4. Refleksi

Kegiatan terakhir dari pengabdian ini adalah refleksi yang dilakukan untuk mengetahui kekurangan atau kelebihan terhadap kegiatan-kegiatan yang telah dilakukan dalam rangka untuk menetapkan rekomendasi terhadap keberlangsungan atau pengembangan kegiatan-kegiatan berikutnya.

\section{HASIL KARYA UTAMA DAN PEMBAHASAN}

Berdasarkan penjelasan tentang metode maka pelaksanaan pengabdian dapat diuraikan dengan kegiatan-kegiatan sebagai berikut :

1. Perencanaan

a. Kegiatan awal

Tim pengabdian mengadakan beberapa kali pertemuan persiapan pelaksanaan pengabdian secara daring. Tim pengabdian terdiri dari ketua pelaksana, anggota pelaksana yang terdiri dari 3 dosen, 2 mahasiswa dan 1 guru SMK Kota Batu yang sekaligus sebagai ketua MGMP Matematika SMK kota Batu. Pertemuan terakhir sebelum pelatihan pertama dilaksanakan pada tanggal 9 Agustus 2021 secara daring. Pada pertemuan tersebut dibicarakan tentang rundown pelaksanaan pengabdian masyarakat untuk guru-guru SMK se Kota Batu dan disepakati model pengabdiannya adalah sinkron dan asinkron. Jadi dua kali pelatihan dan kegiatan mandiri diikuti implementasi soal yang sudah dibuat.

b. Persiapan Pelatihan

Berdasarkan rancangan mekanisme program pengabdian masyarakat seperti di atas, maka hal-hal teknis yang perlu dirancang adalah mendata guru-guru SMK seKota Batu yang merupakan anggota MGMP Matematika SMK Kota Batu, menyiapkan aplikasi zoom dan menyiapkan materi pelatihan (asesmen, aplikasi Kahoot dan model Rasch).

2. Tindakan

a. Pelatihan 1

Berdasarkan hasil identifikasi, hasil analisis permasalahan yang ada, hasil analisis kebutuhan, dan hasil analisis potensi sekolah, selanjutnya disusun program pelatihan 1 yang dilaksanakan pada tanggal 11 Agustus 2021 secara daring. Pembukaan dilakukan tepat pukul 9.00 WIB dengan acara sambutan sekaligus membuka pelatihan oleh ketua MGMP SMK Kota Batu Bapak Joko Santoso dan dilanjutkan dengan sambutan dari pihak Tim pengabdian UM yang diwakili oleh Bapak Swasono Raharjo. Acara pembukaan ini ditutup dengan berdoa yang dipimpin oleh Ketua MGMP Matematika SMK Kota Batu Bapak Achmad Saifudin.

Setelah acara pembukaan dilanjutkan dengan pemateri pertama tentang Penyusunan Soal Matematika untuk siswa SMK oleh perwakilan tim pengabdian UM yaitu Ibu Indriati Nurul Hidayah. Pada materi ini para guru dilatih membuat soal matematika SMK yang baik mulai dari merumuskan indikator, tujuan soal, kunci jawaban dan rubrik penilaian. Sebagian materi tersebut dapat dilihat pada Gambar 1. 


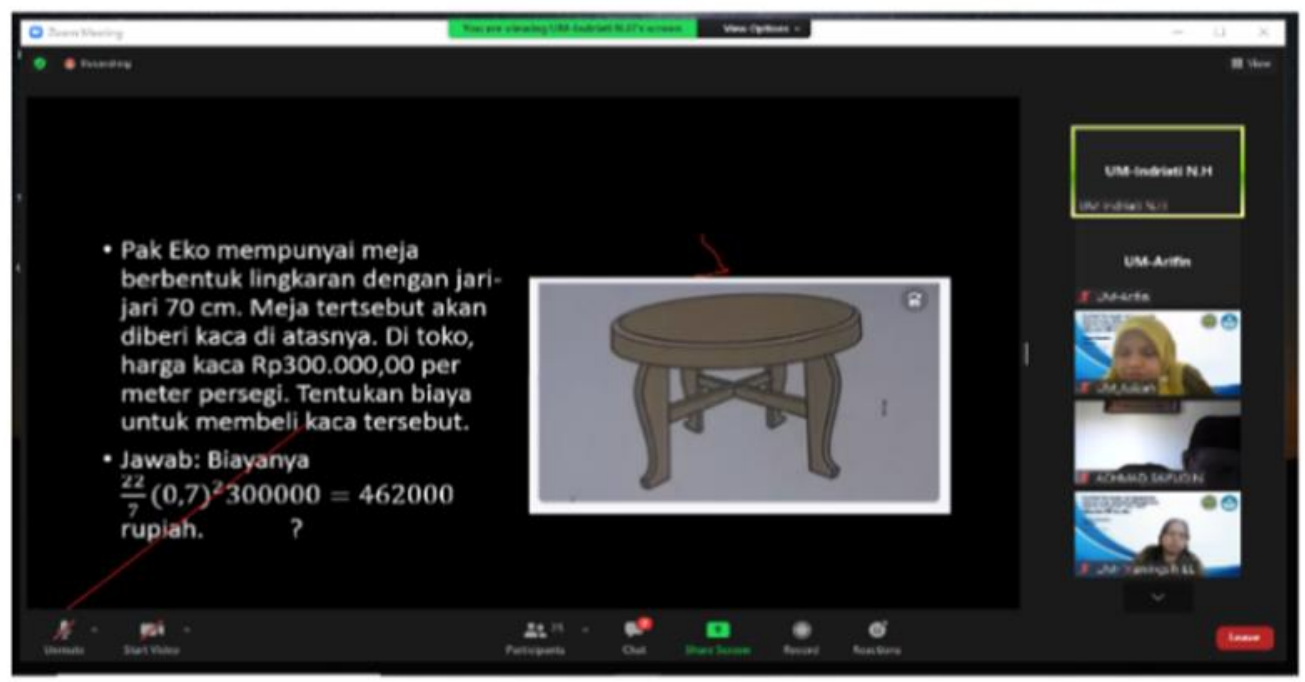

Gambar 1. Kesalahan dalam Penyusunan Soal

Agar suatu tes dapat mengukur apa yang akan diukur oleh pemberi tes,maka hendaknya memenuhi (osterlind, 1998: 700-701):

a. unidimensionality:

Setiap item tes harus fokus pada satu tujuan penilaian atau kemampuan.

b. Local independencetes tersebut :

Setiap butir tes tidak bergantung pada butir lainnya, tanpa petunjuk atau harapan bahwa solusi untuk satu item akan mempengaruhi kinerja pada barang lain.

c. Item characteristic curve:

Jika item valid untuk tujuan tertentu, maka setiap siswa dengan kemampuan masing-masing seharusnya memiliki probabilitas keberhasilan yang sesuai pada item tersebut.

d. Non-ambiguitas:

Item harus dinyatakan sedemikian rupa sehingga bagian dari item akan mengarahkan siswa ke satu persepsi yang benar.

Misalkan, sebuah tes akan mengukur kemampuan pemamhaman konsep siswa, maka tes tersebut harus memnuhi indikator-indikator pemahaman konsep, yaitu (Peraturan Dirjen Dikdasmen Depdiknas Nomor 506/C/Kep/PP/2004 tanggal 11 November 2004)

a. menyatakan ulang sebuah konsep,

b. mengklasifikasi objek menurut sifat-sifat tertentu sesuai dengan konsepnya,

c. memberi contoh dan bukan contoh dari suatu konsep,

d. menyajikan konsep dalam berbagai bentuk representasi matematis,

e. mengembangkan syarat perlu atau syarat cukup dari suatu konsep,

f. menggunakan dan memanfaatkan serta memilih prosedur atau operasi tertentu,

g. mengaplikasikan konsep atau algoritma pada pemecahan masalah.

Setelah pemateri pertama selesai dilanjutkan dengan pemateri kedua tentang Pengenalan Aplikasi Kahoot dan Simulasi Penggunaan Kahoot oleh perwakilan tim pengabdian UM yaitu Bapak Mohammad Agung. Materi 2. Pada kegiatan kedua ini peserta diajak langsung praktek di laptop masing-masing dengan panduan pemateri. Kegiatan dimulai dengan membuka aplikasi Kahoot dan selanjutnya mencoba mengerjakan soal yang sudah disiapkan pemateri. Kegiatan akhir peserta berlatih membuat soal dengan aplikasi Kahoot dan tanya jawab. 
Kegiatan penutupan untuk pelatihan 1 diisi dengan penyampaian informasi kegiatan asinkronus dan persiapan pertemuan ke-2 oleh tim pengabdian UM. Berikut adalah informasi yang diberikan kepada peserta pelatihan dan diharapkan guru-guru dapat mengimplementasikan apa yang sudah diperoleh saat pelatihan 1 .

Kegiatan Asinkron

1) Peserta melakukan uji coba 10 soal pada siswa di kelasnya dengan menggunakan aplikasi Kahoot. Soal yang dipakai adalah soal yang sudah diunggah pada pertemuan 1 sinkron sebelumnya.

2) Peserta menyiapkan soal uraian beserta kunci jawaban dan hasil pekerjaan siswa (boleh hasil yang sudah ada)

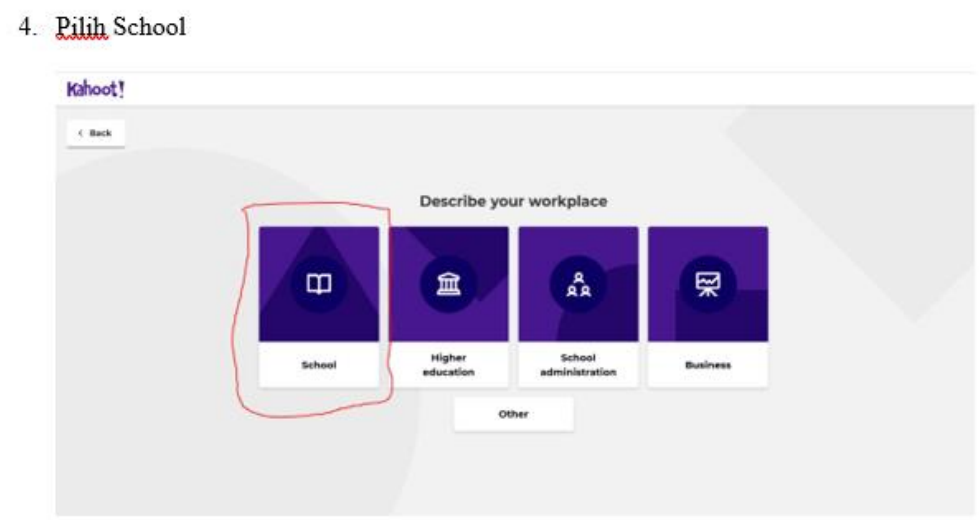

Gambar 2. Contoh materi aplikasi Kahoot

Sebagian peserta yang mengikuti pelatihan 1 secara daring, nampak seperti gambar 3 berikut:

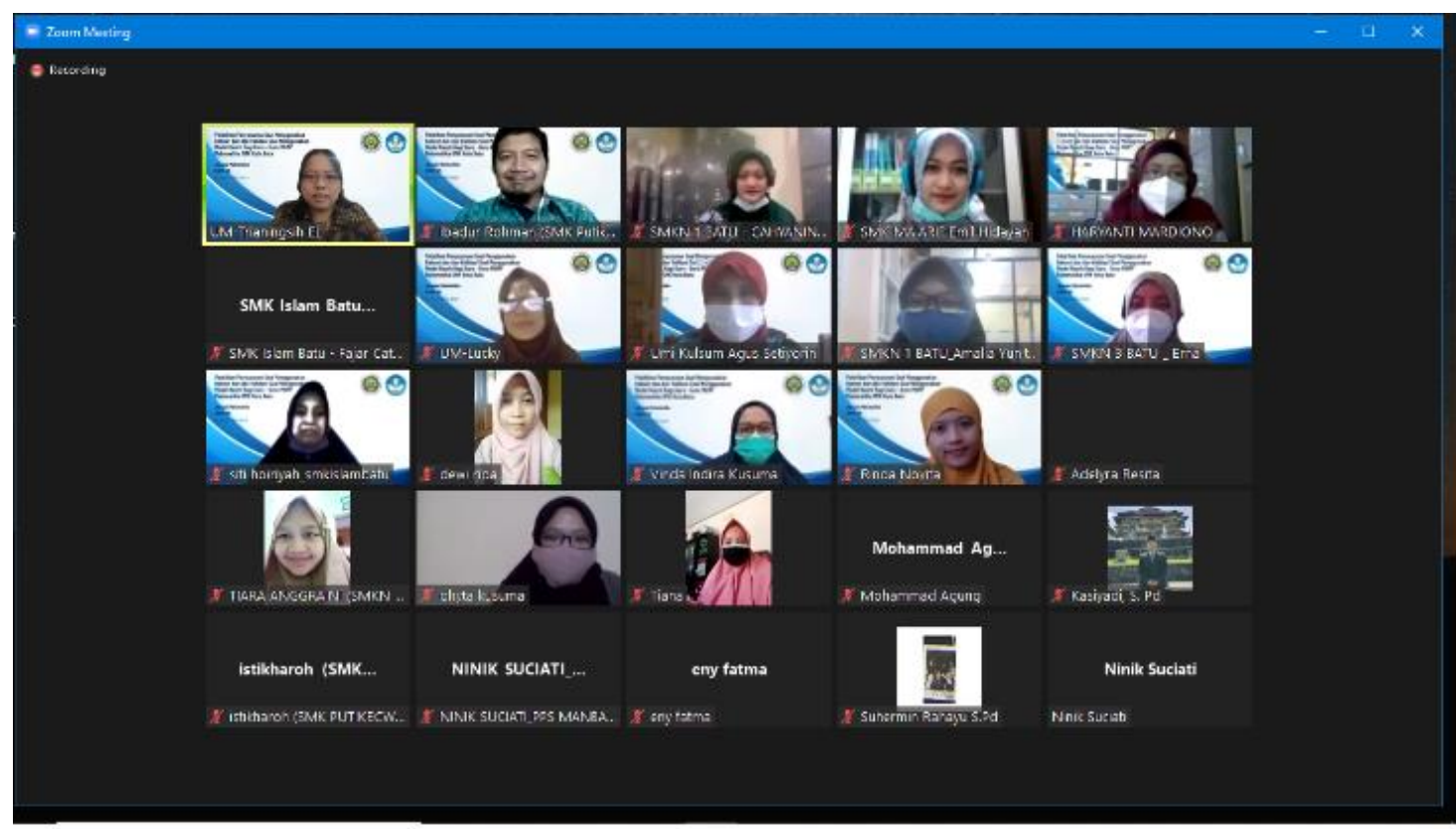

Gambar 3. Foto Bersama di akhir kegiatan pelatihan 1

b. Pelatihan 2

Setelah Pelatihan 1 dan kegiatan asinkron maka kegiatan pengabdian pada masyarakat ini dilanjutkan dengan kegiatan-kegiatan selanjutnya sesuai dengan rancangan yang sudah dibuat. Pelatihan 2 dilaksanakan pada tanggal 4 September 2021. 
Setelah kegiatan asinkron pertama, tanggal 4 September 2021 dilakukan kegiatan pelatihan sinkron yang kedua. Setelah pembukaan oleh Tim pengabdian kegiatan diawali dengan review tugas dari kegiatan pelatihan pertama terutama tentang penerapan aplikasi Kahoot di sekolah.

Pendekatan model Rasch dapat juga digunakan untuk mengetahui kualitas instrumen tes yang digunakan untuk mengetahui kemampuan mahasiswa pada materi aktuaria (Azizah \& Wahyuningsih, 2020).

Masih ada kendala teknis yang dialami guru-guru dalam menerapkan aplikasi Kahoot antara lain guru menganggap pelaksanaan harus klasikal, tentang pin yang berubah dan tentang hasil akhir dari yang ditampilkan Kahoot. Berdasarkan kegiatan pelatihan ini memang waktu yang membatasi tim pengabdian untuk memberikan semua materi kepada guru-guru, sehingga hanya materi dasar yang bisa tersampaikan.

Materi terakhir dari kegiatan ini adalah tentang pemodelan Rasch yang disampaikan oleh Ibu Trianingsih Eni Lestari dan dilanjutkan dengan materi penggunaan ministep untuk validasi soal yang dipandu oleh Ibu Azizah. Sebagian materi nampak pada gambar 4 berikut.

RASCH MODEL- 1

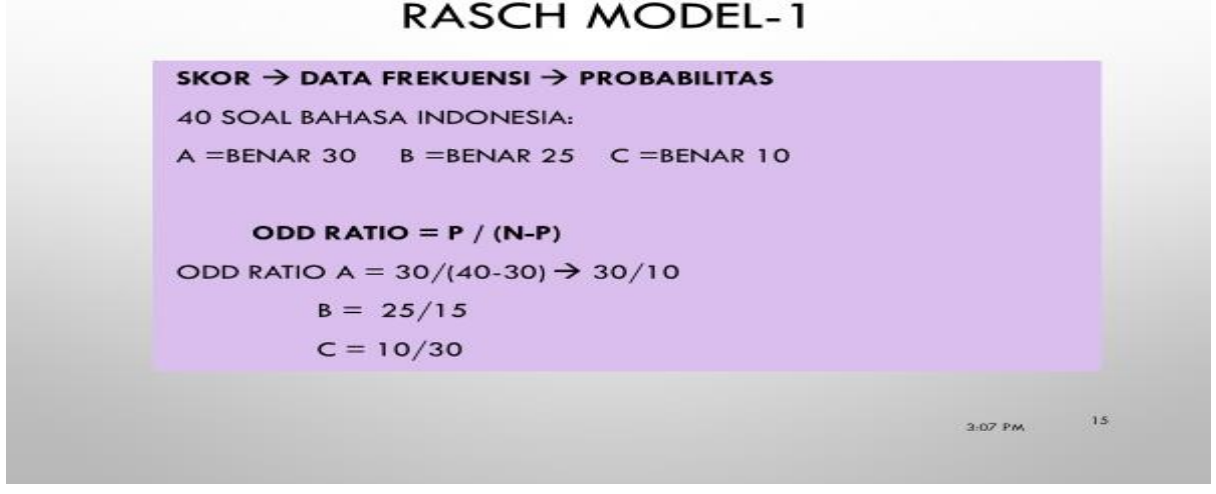

Gambar 4. Contoh Materi Pemodelan Rasch

Pada kegiatan ini guru-guru melakukan praktik penggunaan ministep dan berlatih membaca hasil data yang sudah diolah dalam ministep. Kegiatan pada materi Pemodelan Rasch diakhiri dengan tanya jawab .

\section{CONTOH}

\begin{tabular}{|c|c|c|c|c|c|c|}
\hline No & $\begin{array}{l}\text { Kode } \\
\text { Aitem }\end{array}$ & Logit & $\begin{array}{c}\text { Standard } \\
\text { Error } \\
\text { Measurement }\end{array}$ & $\begin{array}{l}\text { Outnit } \\
\text { MNSOQ }\end{array}$ & $\begin{array}{l}\text { Outnit } \\
\text { ZuTD }\end{array}$ & $\begin{array}{c}\text { Point } \\
\text { Measure } \\
\text { Correlation }\end{array}$ \\
\hline 1 & SAI & $-1,44$ & 0,20 & 0,80 & $-0,86$ & \\
\hline 2 & $\mathrm{SA} 2$ & -0.35 & & & & 0.42 \\
\hline 3 & $\mathrm{SA} 3$ & 0.71 & & 0,82 & & 0,60 \\
\hline 4 & & -0.37 & 0.11 & 0,96 & $-0,16$ & 0.39 \\
\hline 5 & SA5 & 0,46 & $\begin{array}{l}0,08 \\
0.08\end{array}$ & 0.78 & $\begin{array}{l}-1,71 \\
\end{array}$ & 0,61 \\
\hline${ }_{7}^{6}$ & $\begin{array}{l}\text { SA6 } \\
\text { SA7 }\end{array}$ & $\begin{array}{r}0.51 \\
-0.37\end{array}$ & $\begin{array}{l}0,08 \\
0.11\end{array}$ & $\begin{array}{l}0.93 \\
1.20\end{array}$ & -0.48 & $\begin{array}{l}0.52 \\
0.36\end{array}$ \\
\hline 8 & SB1 & $\begin{array}{l}-0,37 \\
1.03\end{array}$ & $\begin{array}{l}0,11 \\
0,08\end{array}$ & $\begin{array}{l}1.20 \\
1.65\end{array}$ & 4,21 & $\begin{array}{l}0,36 \\
0,42\end{array}$ \\
\hline 9 & SB2 & $-0,06$ & 0,09 & 0,93 & $-0,34$ & 0,40 \\
\hline 10 & $\mathrm{SB} 3$ & 0.22 & 0,08 & 2,70 & 7,62 & $-0,02$ \\
\hline 11 & SB4 & -0.16 & 0.10 & 0.94 & -0.25 & 0.42 \\
\hline 12 & SBS & 0,02 & 0,09 & 0,82 & $-1,05$ & 0,41 \\
\hline 13 & SB6 & $-0,36$ & 0,11 & 0.96 & -0.14 & 0.36 \\
\hline 14 & $\mathrm{SCl}$ & $-0,27$ & 0,10 & 0,77 & $-1,24$ & 0,39 \\
\hline 15 & $\mathrm{SC2}$ & 0.21 & 0.08 & 1.10 & 0.67 & 0,32 \\
\hline 16 & SC3 & 0.78 & 0.07 & 1,14 & $\begin{array}{l}1,10 \\
077\end{array}$ & 0,38 \\
\hline 17 & $\begin{array}{l}\text { SC4 } \\
\text { SC5 }\end{array}$ & -0.04 & $\begin{array}{l}0,09 \\
0,09\end{array}$ & $\begin{array}{l}0.86 \\
0.85\end{array}$ & $\begin{array}{r}-0,78 \\
-088\end{array}$ & $\begin{array}{l}0,49 \\
037\end{array}$ \\
\hline $\begin{array}{l}18 \\
19\end{array}$ & SC6 & $\begin{array}{l}-0,12 \\
-0,02\end{array}$ & $\begin{array}{l}0,09 \\
0,09\end{array}$ & $\begin{array}{l}0,85 \\
1,03\end{array}$ & $\begin{array}{l}-0,80 \\
0.25\end{array}$ & 0.33 \\
\hline 20 & $\mathrm{SC7}$ & $-0,36$ & 0,11 & 1,02 & 0,18 & 0.31 \\
\hline
\end{tabular}

Gambar 5. Contoh materi penggunaan Ministep 
Sebelum kegiatan penutupan, tim pengabdian memberikan informasi terkait tugas pada kegiatan asinkron. Berikut tugas yang harus dikumpulkan guru-guru di akhir kegiatan asinkron :

Tugas 1

Buatlah satu soal kontekstual sesuai dengan siswa SMK. Tuliskan

(1) Indikator

(2) Tujuan soal, dijelaskan secara rinci (ingin mengukur apa, misalkan: pemahaman, penalaran, kreativitas, atau apa?)

(3) Soal

(4) Kunci Jawaban

(5) Penskoran

\section{Tugas 2}

(1) Screenshot penerapan Kahoot

(2) Data berupa file Excel dari implementasi Kahoot

Tugas 3

(1) Soal Ujian (word) dan hasil ujian (excel)

(2) Output dan analisis dari nilai ujian yang sudah diolah dengan ministep. Output yang dianalisis mencakup summary statistic (analisis reliabilitas), wright map (pemetaan kemampuan siswa dan tingkat kesulitan soal) dan skalogram (melihat indikasi kecurangan dari siswa)

Setelah pemberian informasi untuk kegiatan asinkron maka dilanjutkan penutupan. Penutupan dilakukan oleh Tim Pengabdian yang diwakili oleh Ibu Trianingsih Eni Lestari.

\section{Observasi dan evaluasi}

Observasi dilakukan terhadap proses pembuatan soal online dengan aplikasi Kahoot dan validasi soal dengan menggunakan ministep oleh guru-guru matematika SMK Kota Batu. Instrumen yang digunakan berupa catatan lapangan. Hasil observasi dari kegiatan pengabdian secara daring (sinkron) ini antara lain adanya kendala jaringan sehingga ada guru yang keluar masuk zoom, pendampingan saat mempraktikkan aplikasi tidak bisa maksimal karena tim pengabdian tidak bisa langsung melihat kesulitan guru saat mencoba aplikasi, serta tim pengabdian tidak bisa melakukan observasi lapangan saat guru mempraktikkan aplikasi kahoot karena proses pembelajaran secara daring. Evaluasi dilakukan terhadap kuantitas dan kualitas produk yang dihasilkan. Produk yang dihasilkan berupa soal online yang sudah dibuat dengan bantuan aplikasi Kahoot dan sudah diaplikasikan kepada siswa serta hasil validasi soal dengan menggunakan mini step. Kuantitasnya dilihat dari berapa produk yang dihasilkan oleh para guru, sedangkan kualitasnya terlihat dari hasil validasi soal yang dibuat menggunakan model Rasch dengan bantuan aplikasi ministep.

\section{Refleksi}

Kegiatan terakhir dari pengabdian ini adalah refleksi, menyusun laporan akhir dan membuat artikel untuk jurnal ilmiah. Refleksi dilakukan untuk mengetahui kekurangan atau kelebihan terhadap kegiatan-kegiatan yang telah dilakukan dalam rangka untuk menetapkan rekomendasi terhadap keberlangsungan atau pengembangan kegiatan-kegiatan berikutnya. Ada beberapa kekurangan saat pelaksanaan yaitu jaringan kurang stabil, tim pengabdian tidak bisa melihat kesulitan guru secara langsung sehingga membutuhkan waktu agak lama untuk memperbaiki kesalahan tersebut, pendampingan kepada guru tidak bisa optimal. Oleh sebab itu perencanaan perlu lebih diperhatikan dalam menentukan berapa lama waktu pelaksanaan dan bagaimana proses daring yang bisa meminimalkan waktu saat ada kesulitan 
penggunaan aplikasi. Misalkan proses daring dengan memberikan aplikasi sebelum pelaksanaan untuk diinstall terlebih dahulu. Dari kegiatan ini pihak MGMP matematika SMK kota batu berharap ada kerjasama lagi dengan pihak UM untuk meningkatkan kemampuan guru-guru matematika.

Kegiatan terakhir dari pengabdian ini adalah menulis laporan akhir, membuat artikel untuk media massa dan artikel untuk jurnal ilmiah.

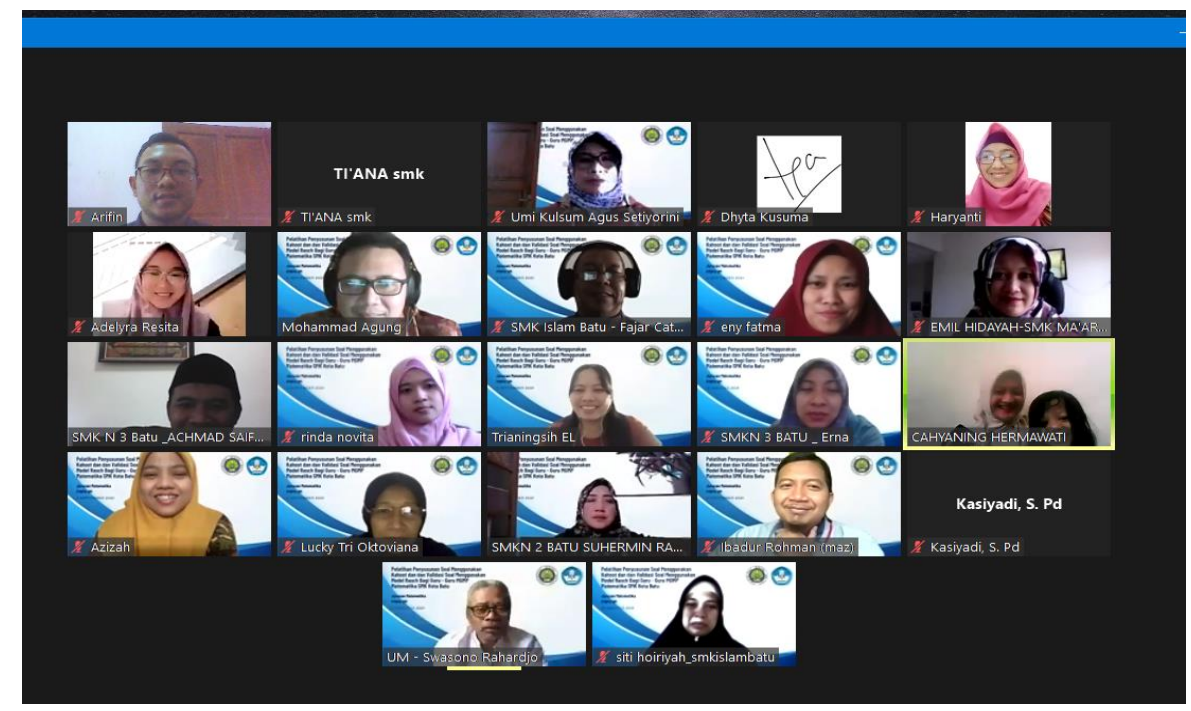

Gambar 6 Foto Bersama di akhir kegiatan pelatihan 2

\section{KESIMPULAN}

Berdasarkan hasil dan pembahasan pelaksanaan pengabdian yang dikemas dalam pelatihan penyusunan soal menggunakan Kahoot dan validitas soal menggunakan Model Rasch dapat disimpulkan bahwa (1) pada masa pandemi ini pembelajaran dilakukan secara daring sehingga agar siswa terpacu untuk belajar maka diperlukan bentuk kuis atau ujian yang menarik, salah satunya dalam bentuk game. Aplikasi Kahoot merupakan salah satu aplikasi yang dapat membantu guru untuk membuat kuis atau ujian dalam bentuk game. (2) guru juga perlu mengetahui apakah siswanya menyelesaikan kuis atau ujian secara mandiri atau tidak. Aplikasi ministep bisa digunakan untuk melihat kemungkinan apakah ada jawaban yang sama, hampir sama atau tidak sama.

\section{UCAPAN TERIMA KASIH}

Tim Penulis mengucapkan terima kasih kepada PNBP Universitas Negeri Malang yang telah memberi dukungan dana terhadap program pengabdian masyarakat ini serta MGMP SMK Kota Batu sebagai mitra dari kegiatan ini.

\section{DAFTAR PUSTAKA}

Azizah, Wahyuningsih S. 2020. Penggunaan Model Rasch untuk Analisis Instrumen Tes pada Mata Kuliah Matematika Aktuaria. J U P I T E K Jurnal Pendidikan Matematika. Volume 3 Nomor 1. https://doi.org/10.30598/jupitekvol3iss1ppx45-50 45

Boone W.J. Rasch Analysis for Instrument Development: Why, When, and How? $\underline{C B E}$ Life Science Education. 2016 Winter; 15(4): rm4. https://doi.org/10.1187/cbe.16-04-0148

Chan, S.W., Ismail, Z., Sumintono, B., 2014. A Rasch Model Analysis on Secondary Students'Statistical Reasoning Ability in Descriptive Statistics. Procedia - Soc. 
Behav. Sci. 129,133-139. https://doi.org/10.1016/j.sbspro.2014.03.658

Garcia Claro, H., Ferreira de Oliveira, M.A., Almeida Lopes Fernandes, I.F. de, Titus, J.C., Ribeiro Tarifa, R., Fernandes Rojas, T., Hayasi Pinho, P., 2015. Rasch model of the GAIN substance problem scale among inpatient and outpatient clients in the city of São Paulo, Brazil. Addict. Behav. Rep. 2, 55-60. https://doi.org/10.1016/j.abrep.2015.08.001

Ginanjar, Darmawan, dan Sriyono. (2019) Faktor-faktor yang Mempengaruhi RendahnyaPartisipasi Belajar Peserta Didik SMK. Journal of Mechanical Enginering Education. Vol 6:2.

Heuvel-Panhuizen, M., Kolovou, A., \& Peltenburg, M. (2011). Using ICT to Improve

Assessment. In B. Kaur \& W. K. Yoong (Eds.), ASSESSMENT IN THE

MATHEMATICS Association of Mathematics Educators Yearbook 2011 (1st ed.).

World Scientific Publishing Co. Pte. Ltd. 5.

Osterlind, S.J. 2002.Constructing Test Items Kluwer Academic Publishers New York, Boston, Dordrecht, London, Moscow

Peraturan Dirjen Dikdasmen Depdiknas Nomor 506/C/Kep/PP/2004 tanggal 11 November 2004

Rafnis, 2018. Pemanfaatan Platform Kahoot Sebagai Media Pembelajaran Interaktif. ETech: Jurnal Ilmiah Teknologi Pendidikan DOI : https://doi.org/10.24036/et.v2i2.101336

Rohma, A.K. 2018. Pengaruh Pengunaan Media Gambar/Foto Terhadap Minat Belajar Siswa pada Mata Pelajaran Pendidikan Agama Islam Kelas VIII di SMPN 2 Ngantru Tulungagung. Skripsi tidak diterbitkan. IAIN Tulungagung. http://repo.iaintulungagung.ac.id/id/eprint/8552

Sabandar, G. N. ., Supit, N. R., \& Suryana, H. T. . (2018). Kahoot !: Bring the Fun Into the Classroom! Indonesian Journal of Informatics Education, 2(2), 127-134. https://doi.org/10.20961/ijie.v2i2.26244

Sahronih, S., Purwanto, A., Sumantri, M.S. 2019. The Effect on Interactive Learning Media on Students' Science Learning Outcomes. ICIET 2019: Proceedings of the 20197 th International Conference on Information and Education Technology. March 2019. Hal.20-24. https://doi.org/10.1145

Sulasteri, S., Rasyid, M.R., Akhyar, M. 2018. The Effect of the Use of Learning Media Based on Presentation Media on Interest and Mathematical Learning Outcomes. MaPan: Jurnal Matematika dan Pembelajaran. 6(2): 221-236. https://doi.org/10.24252/mapan.2018v6n2a8

Wahyuni, W. 2016. Pengaruh Penggunaan Media Pembelajaran Terhadap Minat Belajar Siswa di SMK YPLP PGRI 1 Makassar. Skripsi tidak diterbitkan. Universitas Negeri Makassar. http://eprints.unm.ac.id/id/eprint/6182.

Yasin, R.Mohd., Yunus, F.A.N., Rus, R.C., Ahmad, A., Rahim, M.B., 2015. Validity and Reliability Learning Transfer Item Using Rasch Measurement Model. Procedia - Soc. Behav. Sci. 204, 212-217. https://doi.org/10.1016/j.sbspro.2015.08.14qw 